\title{
水素放出に及ぼすステンレス鋼の表面加工の効果
}

板倉 明子*1・村瀬 義治*1.土佐 正弘 $* 1$

鈴木 真司 $* 2 \cdot$ 高木 祥示 $* 2 \cdot$ 後藤 哲二 $* 2$

\section{Effect of Surface Processing on Hydrogen Desorption from Stainless Steel to UHV}

\author{
Akiko N. ITAKURA*1, Yoshiharu MURASE*1, Masahiro TOSA*1, \\ Shinji SUZUKI*2, Shoji TAKAGI*2 and Tetsuji GOTOH*2 \\ *1National Institute for Materials Science, 1-2-1 Sengen, Tsukuba-shi, Ibaraki 305-0047, Japan \\ *2Department of Physics, Toho University, 2-2-1 Miyama, Funabashi-shi, Chiba 274-8510, Japan
}

(Received June 7, 2013, Accepted October 22, 2013)

\begin{abstract}
Electron Stimulated Desorption (ESD) is one of surface analysis techniques using an excitation of adsorbed atoms by electrons. Using a scanning electron beam it is possible to map a two dimensional ESD distribution of adsorbed hydrogen. We detected striped pattern of hydrogen desorption from the stainless steel surface flattened by the processing with the lathe. The hydrogen gas was supplied to backside of the sample membrane, penetrates the sample inside, and arrives at the surface. The ESD pattern of hydrogen reflects density of the dislocation in martensite that occurred by lathe processing on the austenite steel surface.
\end{abstract}

\section{1. 序 論}

金属材料内部及び金属表面の水素の挙動測定は，構造材の 水素脆化や金属鋼の寿命を評価する上で重要であり 1,2$)$, 金 属鋼の寿命の実測と同時に，材料中の水素を測定する核磁気 共鳴法3,4)，X 線回折法などで構造変化から間接的に検出す る万法5), 昇温脱離法6) により直接水素を検出する手法など で測定が行われている．また，超高真空，極高真空に抢ける 残留ガスの主成分は水素であり, 水素を排気するポンプの開 発や, 水素の放出を制御する表面処理法が研究されてお $\eta^{7-9)}$, 表面処理により水素放出量がひと桁から二桁下がる ことが知られている.しかし, 到達圧力（つまり処理を施し た真空容器全体を平均化したガス放出）を論じる場合がほと んぞで, 平坦加工の形状や, 表面処理の際に真空容器の母材 に生じた加工転位等が，ガス放出に及ぼす局所的な効果に焦 点を当てた報告は少なく, 極高真空装置内の水素が容器内の 大気が残留したものなのか, 容器壁から発生（容器壁から脱 離, あるいは容器外部から透過）してきたものなのか，厳密 に考察されることはなかった。

局所構造を反映した水素測定を行うため, 水素の表面濃度 分布を直接検出できる電子衝撃脱離（Electron Stimulated Desorption；以下 ESD）法を用いた. ESD は低速の電子線 を用いて表面の吸着物を電子的に励起し，イオンとして脱離 させ，検出する手法である ${ }^{9,10)}$. 走査電子顕微鏡の電子線を 電子源とし, 試料表面を走查して, 二次電子像と脱離水素イ オン像を交互に撮影する事により, 表面形状や表面状態を反 映した解析を行う事が可能である11)。

水素放出の局所情報を測定する装置を作り，一般的な構造 材料であるステンレス鋼について, 水素放出の局所温度依存 性を測定したところ, 薄板加工時の効果と思われる表面形状 の影響を検出したので，報告する.

*1 物質 · 材料研究機構 $(\overline{\mathbf{T}} 305-0047$ 茨城県つくば市千現 1-2-1)

*2 東邦大学理学部（元274-8510 千葉県船橋市三山 2-2-1)

\section{2. 実験}

既存の電子顕微鏡（JEOL, JUMP-10）に Fig. 1 の改造 を施した．試料薄板によって超高真空容器を水素室と ESD 測定室に分割し, 試料の背面の水素室から供給された水素 が，試料に侵入，拡散し， ESD 室側の試料表面に透過する 現象を実時間で測定する.

従来の測定室である $\mathrm{ESD}$ 室の到達圧力は $3 \times 10^{-7} \mathrm{~Pa}$, 水 素室はターボ分子ポンプで排気したのち， $0.05 \sim 0.1 \mathrm{MPa}$ の 範囲で水素ガスを供給した。試料は試料背面からハロゲンラ ンプを用いて室温から $300^{\circ} \mathrm{C}$ まで段階的に加熱し, 薄板に直 接スポット溶接した T 熱電対（銅コンスタンタン）で温度 測定した．画像の熱ドリフトを補正するため，昇温毎に測定 位置の調整を行い，二次電子像と ESD イオン像を交互に撮

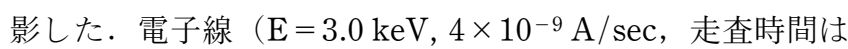

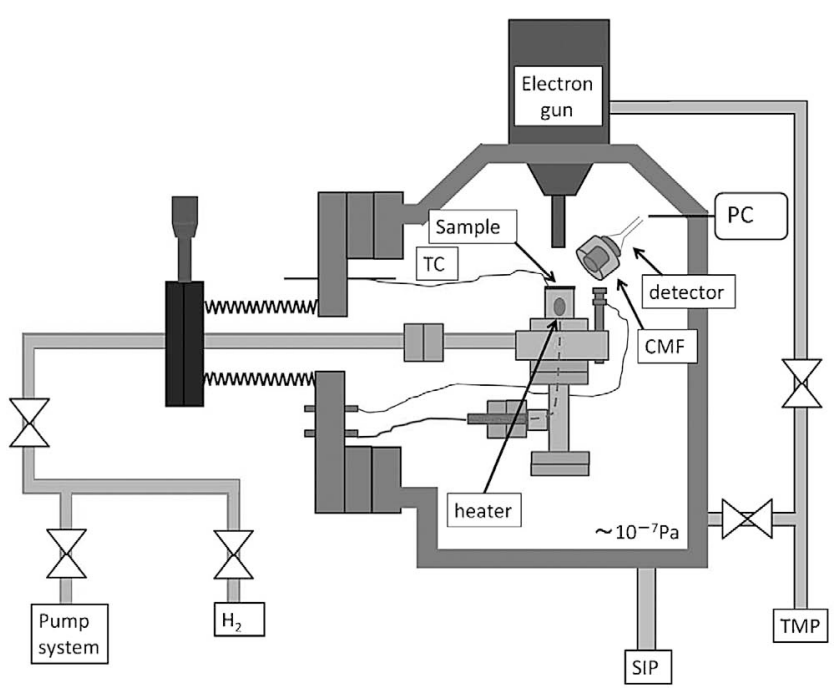

Fig. 1 Schematic diagram of experimental apparatus. Hydrogen filled into gray shadowed area, which separated from UHV chamber with a thin sample membrane. 

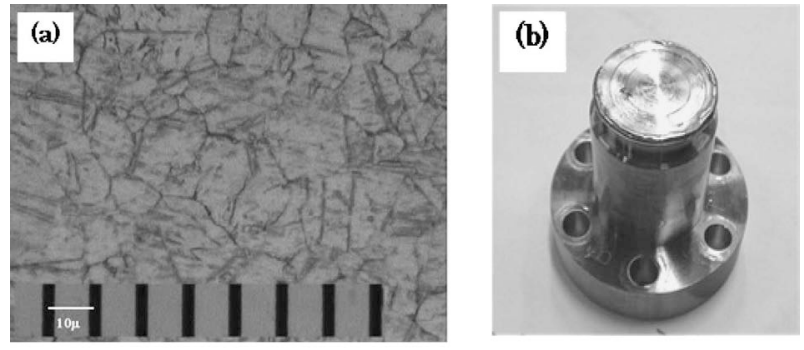

(c)

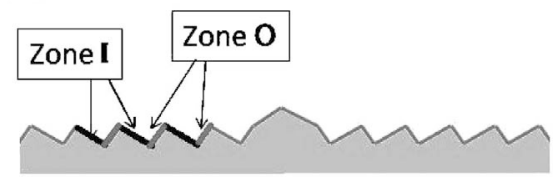

Fig. 2 (a) Surface view of SUS304 sample, with optical microscope. (b) Photo of SUS304 sample welded to ICF34. (c) Schematic diagram of the surface geometry.

$400 \mathrm{sec} /$ frame なので，撮影中のドーズ量はおよそ $2.0 \times 10^{21}$ electrons $\left./ \mathrm{m}^{2}\right)$ は試料垂直方向から照射され，ESD イオン は試料法線方向から 45 度の位置に設置されたイオン検出機 （チャンネルトロン）によって検出される．電子線入射時に 発生する光や散乱電子はイオン検出器の前に置いた同軸円筒 鏡型のフィルターで除去し，ESD イオンのみを検出した。 ESD イオン像は定められた温度に対して10枚連続撮影し， その累積, 打よび平均で結果を解积した。

試料はステンレス鋼 SUS304鋼を用いた.オーステナイト 構造の中にマルテンサイト転位が入った構造であることを， X 線散乱（リガク，RINT2500）により確認した．試料の光 顕微鏡写真を Fig. 2 (a) に示す. 10-50 $\mu \mathrm{m}$ の結晶粒とその 中の転位が確認された。この母材を旋盤加工で $300 \mu \mathrm{m}$ まで 薄膜化し, ICF34フランジに低温で溶接した. 溶接時の試料 中央部の温度上昇は, $100^{\circ} \mathrm{C}$ 以下であることを確認している.

ESD の観察表面には, 表面を平坦化した時の旋盤加工に よる引き目が残っている (Fig. 2 (b) 参照)。旋盤加工は外周 から内に向かって切削したため, 引き目の断面は対称ではな い. 以降, 円艋形状の試料の中心に向かって傾斜した面を I 面，外側に向かって傾斜した面を O 面と呼ぶ. Fig. 2(c) に, 試料中心を通る直線で断面図を, 模式的に示す. プロフ アイラ（東京精密株式会社, SURFCON480A) で形状測定 したところ,引き目のピッチは $40 \mu \mathrm{m}$, 深さは 7-9 $\mu \mathrm{m}$, 平 均斜度は 11 度と 32 度, 表面粗さは $0.3 \mu \mathrm{m}$ 以下だった。試料 の清浄化として, 試料薄板及びミニフランジ全体をエタノー ルで超音波洗浄した後, 真空容器に組み込反, 装置全体と同 時に $100^{\circ} \mathrm{C}$ 程度のベーキング処理をした。

ESD 実験中の測定室の残留ガスを四重極型質量分析器で 分析し, ガス放出の $99 \%$ 以上が水素であることを確認して いる.この結果から, 試料表面からの ESD イオンは, 水素 イオンと考えて議論する.

\section{3. 結果と考察}

\section{1 水素放出の形状依存性}

Fig. 3(b) (c) は, 試料表面の同一の場所の電顕写真（二次 (a)

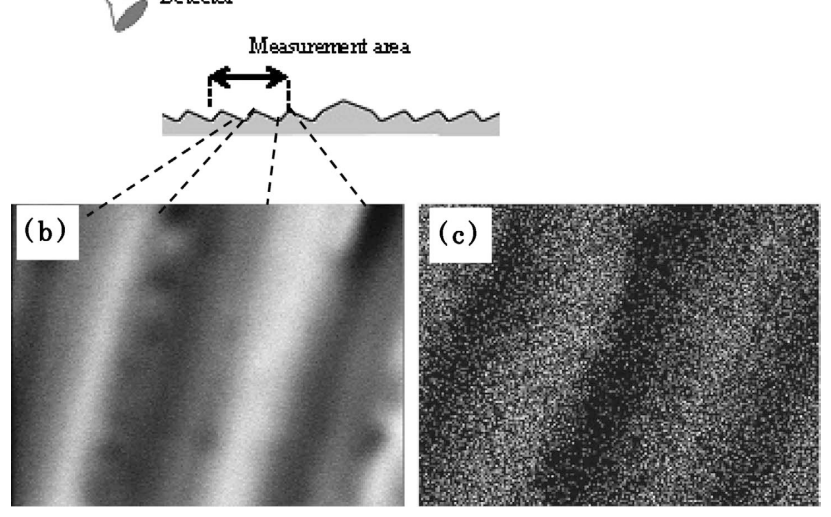

Fig. 3 (a) Schematic diagram of measurement area and detector position. (b) SEM picture of SUS304 sample in length of $80 \mu \mathrm{m} \times 62 \mu \mathrm{m}$. (c) ESD mapping of the same area with (b). Bright spots are desorbed $\mathrm{H}+$ ions. Bright lines are the area of zone $\mathrm{O}$ and dark lines are zone $\mathrm{I}$.

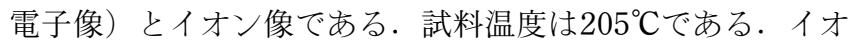
ン像の明点 1 個は水素イオン 1 個に対応し, 明線は $\mathrm{O}$ 面, 暗線は I 面に対応する (模式図 (a)参照)。二次電子像抢よび イオン像に，旋盤の引き目周期に相当する $40 \mu \mathrm{m}$ 周期の明暗 の線が確認された．それぞれの領域で, $5.8 \mu \mathrm{m} \times 2.9 \mu \mathrm{m}$ の エリアを任意に 10 か所選び，イオン数をカウントし，見か け上の脱離数を計測すると，O 面㧍よび I 面からの脱離する

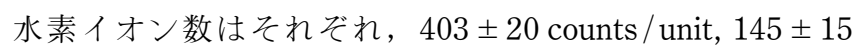
counts/unit となった．この值は表面に吸着した水素が余弦 法則に従って等方的に脱離すると仮定し，表面傾斜の違いに よる検出器への入りやすさを考慮して校正すると, 法線方向 への脱離は $\mathrm{O}$ 面が 413.7 counts / unit, I 面が 259.8 counts / unit となる. 斜面の傾斜の効果のみでは, それぞれの面から の脱離数は一致せず，有意な差があることが分かった．

試料である304鋼には，オーステナイト構造にマルテンサ イト転位が含まれていることを確認している，旋盤加工に抄 ける剪断応力により, 加工誘起マルテンサイト変体が O 面 に扔いてさらに助長されたと考元られる12,13). 水素の拡散速 度は, オーステナイト構造に比較し, マルテンサイト構造で 大きく ${ }^{14,15)}$ ，その結果 O 面にはマルテンサイト構造を透過 した水素が多く表面に滞在し，ESDによる脱離数が大きく なったと推測する．Ｏ面とI面では加工方向による剪断応力 のかかり方が異なり，旋盤加工時の刃が当たる力（測定領域 付近での回転速度 $540 \mathrm{deg} / \mathrm{sec}$, 送り速度 $40 \mu \mathrm{m} /$ round） が 大きい $\mathrm{O}$ 面でのマルテンサイト中転位の数が，I面よりも大 きくなったと考えられる12,13,16-18).

\section{2 水素イオン放出の温度依存性}

脱離イオン数の温度依存性を測定した．Fig. 4 の縦軸は 面の傾斜の効果を補正した脱離数，横軸はそれぞれの温度で ある. ○は $\mathrm{O}$ 面からの脱離数, ○は I 面からの脱離数を示 す．Ｏ面とI面との温度依存性が異なって抢り，すべての温 度領域において，O面からのイオン脱離量が大きいことがわ かった．また，温度依存性は面によって異なり，O面からの 脱離イオン数に大きな温度依存性がないのに対し，I面から 


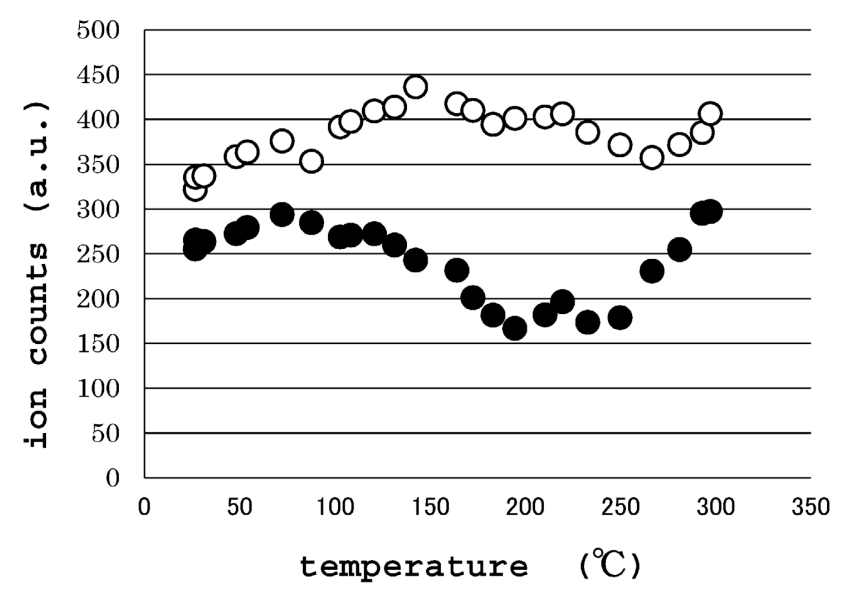

Fig. 4 Temperature evolution of ESD ions from zone O (mark $\bigcirc$ ) and zone I (mark $\mathbf{O}$ ). Waiting time is $1800 \mathrm{~s}$ for each point.

の脱離イオンは, $50-200^{\circ} \mathrm{C}$ の範囲でおよそ半数まで減少 し, 温度 $250^{\circ} \mathrm{C}$ 以上で再び上昇した. 我々は理由を以下のよ うに考察した.

検出された水素イオンは, 鋼材にもともと含まれていた残 留水素, 薄板試料の背面から拡散したもの, 真空側から表面 に吸着したものすべてが測定表面に滞在し, 電子衝撃により 励起, 脱離するものすべてを含む. このうち, 残留水素は薄 板内に均一に分布していると考えられ，濃度勾配による水素 の流れはない。 また, 昇温により薄板内の拡散が促進される とともに測定表面での熱脱離（TD）も盛んになる．表面に 滞在している水素には ESD と TD の双方が起き, これらの 脱離速度と薄板内拡散の動的バランスの上で表面水素濃度が 決まっているＥSDの温度依存性はないと仮定できるが， 一方，ステンレス鋼からの水素の昇温脱離ピークは $150^{\circ} \mathrm{C}$ 付 近と， $300^{\circ} \mathrm{C}$ 付近にあることが分かって抢り ${ }^{19)}$ ，その双方の 効果を考察することにする.

オーステナイト鋼とマルテンサイト鋼内の水素の侵入（拡 散）量を Mathematica（ウルフラム・リサーチ）で計算し た. Fig. 5 は，ステンレス鋼の表面から深さ $300 \mu \mathrm{m}$ の場所 に拡散する水素量の時間変化である。低温では，10-1000秒 の拡散時間の範囲でオーステナイト鋼とマルテンサイト鋼と 差が顕著である. $200^{\circ} \mathrm{C}, 1000$ 秒において, 拡散水素量の差 が最も大きく, Fig. 4 の二つのエリアからの水素イオンの差 が，最も大きくなる部分と一致している.

この実験では, 測定点一点につき 1800 秒間一定温度に保 持した後, ESDの実験を開始した。試料はオーステナイト (拡散係数 $4 \times 10^{-16} \mathrm{~m}^{2} / \mathrm{s}$ ) なので, 我々の用いた保持時間 々 $200^{\circ} \mathrm{C}$ 以下の状態では, 背面からの拡散量が十分ではな く, 脱離数に比較して拡散 ·表面に供給される水素原子数が 小さい拡散律速状態であったと考えられる．この温度範囲に 扔いては非平行な状態であり, 低温側での表面水素濃度の上 昇は背面からの透過による水素ではなく, 残留水素によるも のと考えられる. $200^{\circ} \mathrm{C}$ 以上では, 拡散速度が測定条件内で 薄板を透過するのに十分になるため, 背面からの水素拡散に より表面水素濃度が増大したと考えられる。また，O面にお

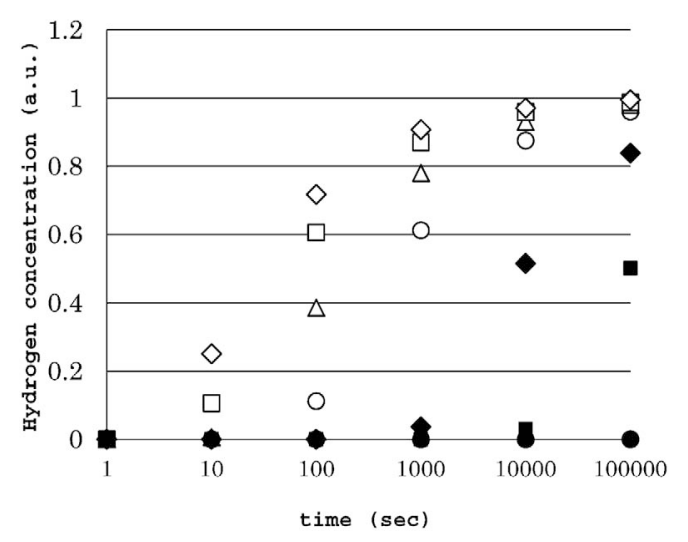

Fig. 5 Time evolution of hydrogen concentration in steel at $300 \mu \mathrm{m}$ depth from the surface. Open markers show martensite steel at the temperature of $\bigcirc: 300 \mathrm{~K}, \triangle: 373 \mathrm{~K}, \square: 473$ $\mathrm{K}$, and $\diamond: 573 \mathrm{~K}$. Solid markers show austenite structure at the temperature : $300 \mathrm{~K}, \mathbf{\Delta}: 373 \mathrm{~K}, \mathbf{\square}: 473 \mathrm{~K}$, and $\bullet: 573$ $\mathrm{K}$.

いては, 水素の拡散係数がオーステナイトに比べて 5 桁大 きいマルテンサイト構造が多く含まれているので, マルテン サイト $\left(1.8 \times 10^{-10} \mathrm{~m}^{2} / \mathrm{s}\right)$ を介して水素が拡散し, 表面に 供給されるため脱離数の減少が見られなかったと推測する.

加工効果による転位は，表面近傍およそ数十 $\mu \mathrm{m}$ の範囲で あるといわれる13). 各々の水素原子をランダムウォーク的 に考え，水素がオーステナイトとマルテンサイトの理想的な 境界サイトに来たときのホッピングのバリアーが異なるた め, ほとんどの水素原子がマルテンサイト側に移動し, マル テンサイト側の表面水素密度が上昇したことが予測される.

しかしながら, 現段階では, 表面近傍で起きている現象を完 全に解明するには至っていない.

\section{3 表面分析}

ステンレス鋼の表面分析では，加工時や昇温時にイオンな ぞの不純物の表面偏析が起きることが，古くから知られてい る $^{20-22)}$. 偏析物質による水素拡散障壁の可能性を確認する ため, ESD 実験の後の試料表面を, エネルギー分散型 X 線 分析（JEOL JED2300）により測定した. Fig. 6(a)は, 鉄 及びクロムの表面元素分布, (b) は酸素の分布である. 鉄及 びクロムが均一に存在しているのに対し, 酸素には $40 \mu \mathrm{m}$ 周 期の変動が見られ，O面で酸素量の多いことが分かったＯ 面でのマルテンサイト転位量の多さから昇温実験中に酸化が 促進された可能性, および, 表面平坦化の加工時に, 局所的 に温度が上がりI面よりも酸化が進んだ可能性の双方が考え られる．実験で用いた温度はステンレス鋼の熱酸化を起こす には十分でないが，水素が酸化促進に関与した可能性も排除 できない。また，ステンレスの酸化表面からの水素の放出 は, 酸化していない表面よりも少ないという報告がある7). 酸化によって O 面とI面の水素拡散量の違いが，小さく見 積もられている可能性が高い.

\section{4. まとめ}

背面から供給され, 薄板形状の試料を透過した水素を, 電 子衝撃脱離で検出する装置を作製した. 旋盤加工で平坦化 

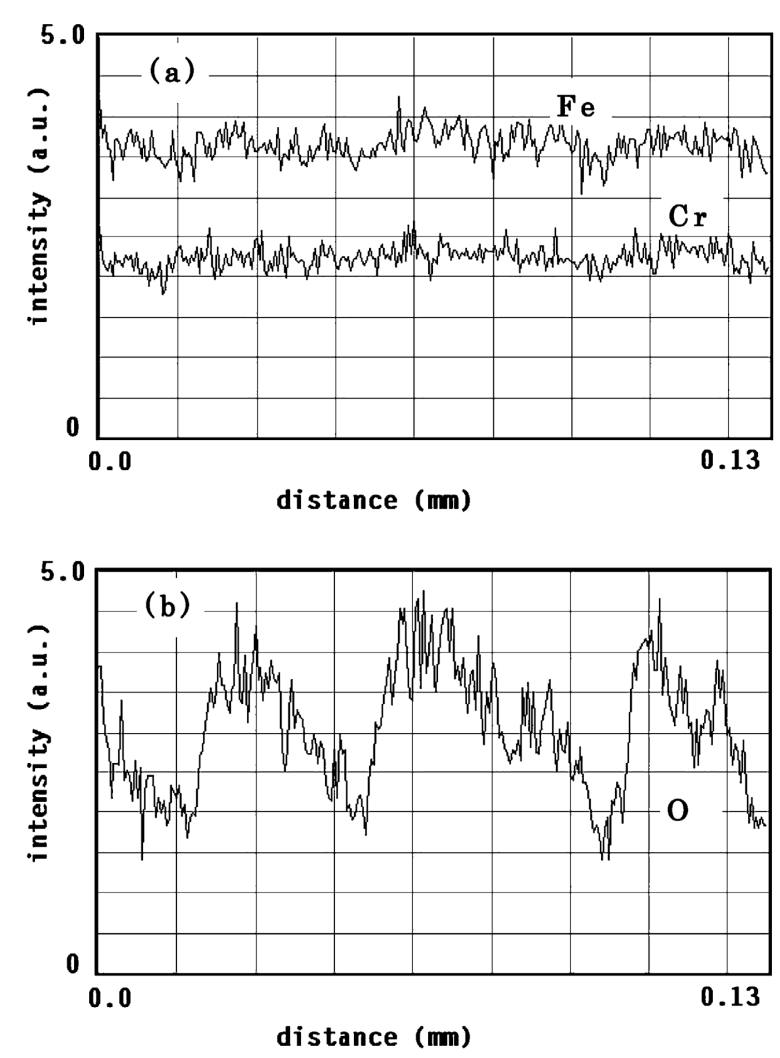

Fig. 6 Intensities of Iron and Chromium (a) and Oxygen (b) measured by EDX (Energy Dispersive X-ray spectroscopy).

し，引き目の残るオーステナイト系ステンレス鋼表面から， 表面の形状を反映した ESD パターンが得られた．形状の違 いによる水素放出量の差は, 加工時の応力によって表面近傍 に構造の変化が生じることによって，水素の拡散と脱離に影 響を及ぼしたと考えると説明ができる。水素の拡散速度は オーステナイト構造に比較してマルテンサイト構造では大き く, 加工方向からマルテンサイト転位が多いと推測される部 位で, 水素イオン脱離量が大きいことと, 矛盾しない結果が 得られた。

今後, 局所的なオーステナイトとマルテンサイトの比率を
測定して表面水素分子密度を見積もり，水素放出の定量的な 解釈につなげたい。

謝辞

この研究は, 科学研究費補助金により行われました.

\section{〔文献〕}

1) G. P. Tiwari, A. Bose, J. K. Chakravartty, S. L. Wadekar, M. K. Totlani, R. N. Arya and R. K. Fotedar: Mater. Sci. Eng. A, 286 (2000) 269.

2) M. Wang, E. Akiyama and K. Tsuzaki: Collision Science, 49 (2007) 4081.

3) K. Asano, S. Hayashi, Y. Nakamura and E. Akiba: J. Alloys Compd., 507 (2010) 399.

4) H. Shao, K. Asano, H. Enoki and E. Akiba: J. Alloys Compd., 477 (2009) 301.

5) Y. Nakamura, J. Nakamura, K. Sakaki, K. Asano and E. Akiba: J. Alloys Compd., 509 (2011) 1841.

6) G. Raiteri and A. Calcatelli: Vacuum, 62 (2001) 14.

7) Y. Ishikawa and V. Nemanic: Vacuum, 69 (2003) 501.

8) A. Itakura, M. Tosa, S. Ikeda and K. Yoshihara: Vacuum, 47 (1996) 697.

9) M. Tosa, A. Kasahara, A. Itakura and K. Yoshihara: Journal of Surface Analysis, 4 (1998) 320.

10) S. Takagi and T. Gotoh: Surf. Sci., 287-288 (1993) 361.

11) A. Yamaga, K. Hibino, M. Suzuki, M. Yamada, K. Tanaka and K. Ueda: J. Alloys Compd., 460 (2008) 36.

12) I. Tamura: Met. Sci., 16 (1982) 245.

13) M. Martin, S. Weber, C. Izawa, S. Wagner, A. Pundt and W. Theisen: Int. J. of Hydrogen Energy, 36 (2011) 11195.

14) T.-P. Perng and C. J. Altstetter: Acta Metall., 34 (1986) 1771.

15) V. Olden, C. Thaulow and R. Johnsen: Mater. Des., 29 (2008) 1934.

16) K. Spencer, J. D. Embury, K. T. Conlon, M. Véron and Y. Bréchet: Mater. Sci. Eng. A, 387-389 (2004) 873.

17) M. Umemoto, Y. Todaka and J. Li: Tetsu-to-Hagané, 94 (2008) 616.

18) M. Hayashi: J. Soc. Mat. Sci. Japan, 44 (1995) 745.

19) K. Takai, K. Murakami, N. Yabe, H. Suzuki and Y. Hagihara: J. Japan Inst. Metals, 72 (2008) 448.

20) C. L. White, R. A. Padgett, C. T. Liu and S. M. Yalisove: Scripta Metallurgica, 18 (1984) 1417.

21) J. Oudar: Mater. Sci. Eng., 42 (1980) 101.

22) K. Muraki, S. Fukatsu, Y. Shiraki and R. Ito: Appl. Phys. Lett., 61 (1992) 557. 